\title{
Genetic and Metabolic Variability between Two Subspecies of Chamaeleo chamaeleon (Reptilia: Chamaeleonidae) in Egypt
}

\author{
Mohamed A. M. Kadry*, Hanan R. H. Mohamad \\ Zoology Department, Faculty of Science, Cairo University, Cairo, Egypt \\ Email: ecokadry@yahoo.com
}

Received 5 May 2014; revised 15 June 2014; accepted 11 July 2014

Copyright @ 2014 by authors and Scientific Research Publishing Inc.

This work is licensed under the Creative Commons Attribution International License (CC BY). http://creativecommons.org/licenses/by/4.0/

(c) (i) Open Access

\section{Abstract}

The degree of variability between two subspecies of Chamaeleo chamaeleon; $C$. chamaeleon chamaeleon inhabiting El-Dabaa (MarsaMatrouh) and C. chamaeleon musae inhabiting El-Arish (North Sinai) of Egypt was investigated in this study using polyacrylamide gel electrophoreses for Lactate dehydrogenase $(L d h)$ and Alfa-esterase $(\alpha-E s t)$ isoenzymes. Total lipids and proteins of liver and muscle tissues in both species were analyzed. Three $L d h$ isoforms were recorded for both subspecies and the activity. Rate of flow (RF) of $L d h-1$ seemed to be higher in $C$. chamaeleon chamaeleon than in $C$. chamaeleon musae. This high activity could be supported by the significant increase in the total lipids and proteins in liver and muscle tissues of this species. It may thus be reasonable to suppose that $C$. chamaeleon chamaeleon is more active, energetic and adaptable in its habitat than C. chamaeleon musae. The $\alpha$-Est showed four fractions in both subspecies. The null variations in the activity of $\alpha$-Ests in the studied tissue may indicate, to some extent, the safety of the diet applied to both subspecies of chameleons.

\section{Keywords}

Electrophoreses, Physiological Ecology, Chamaeleonidae, Isoenzymes, Lipids, Proteins

\section{Introduction}

East Africa has a diverse chameleon fauna with over 50 species described to date. These species are mostly regional endemics restricted to highlands areas and adapted to cooler and higher rainfall environments [1]. The Common Chameleon, Chamaeleo chamaeleon, belongs to the family Chamaeleonidae. These Old World lizards possess unique features that make them easily distinguishable from other lizards. Included in the features are 
their zygodactyl feet and laterally compressed body. Their adjacent digits are fused on each foot, forming opposing grasping pads [2].

Chamaeleonidae is composed of six genera, which include Bradypodion, Brookesia, Calumma, Chamaeleo, Furcife, and Rhampholeon [3]. The Common Chameleon features the broadest distribution of all chameleon species, found from Morocco and the southern Iberian Peninsula over the whole of North Africa, to the Near East, Turkey, Cyprus and Southern Arabia [4]. The genus Chamaeleo contains 4 recognized subspecies: C. c. chamaeleon, C. c. musae, C. c. orientalis, and C. c. rectricrista. The subspecies; C. c. chamaeleon and C. c. musaeare allocated from North Africa, Middle East, Morocco, Algeria, Tunisia, Libya, Egypt, Israel, Palestine, Jordan, Western Sahara, Saudi Arabia, Yemen, Lebanon, Syria, Iraq, and Iran [5].

Isoenzymes are multiple forms of a single enzyme, which often have different isoelectric points and therefore can be separated by electrophoresis. Ldhsisozymes are systems very suitable for our examination of several metabolic, genetic, ecological features, and very useful in systematic studies [6]. Ldhs as a kind of hydrogen transfer enzyme, catalyze the oxidation of L-lactate to pyruvate with nicotinamide-adenine dinucleotide (NAD)+ as hydrogen acceptor, which constitutes the final step in the metabolic chain of anaerobic glycolysis. Esterase isoenzymes (Ests), as one of the lipid-hydrolyzing enzymes, possess high significance in genetics and toxicology [7].

Electrophoresis is a versatile biochemical technique to detect genetic variation between subspecies depending on the migration of the charged molecules, such as isoenzymes, in an electric field [8]. Thus the present study aims to investigate the patterns of inter-specific genetic and biochemical variations between two subspecies of $C$. chamaeleon (C. chamaeleon chamaeleon and C. c. musae) in the coastal and Sinai deserts of Egypt.

\section{Materials and Methods}

\subsection{Taxon Sampling and Study Area}

A total of 10 samples from 2 Egyptian subspecies of chamaeleonid lizards; C. c. chamaeleon and C. c. musae were collected from El-Dabaa (Marsa Matrouh) and El-Arish (North Sinai) respectively [31 ${ }^{\circ} 01^{\prime} 37.49^{\prime \prime} \mathrm{N} 28^{\circ} 26^{\prime}$ 8.48"E and 31 $07^{\prime} 55.53^{\prime \prime} \mathrm{N} 33^{\circ} 48^{\prime} 11.79 " \mathrm{E}$ respectively] (Figure 1).

\subsection{Sample Preparation and Isoenzyme Assay}

Tissue samples of liver and heart were removed, immediately taken to the lab, and stored at $-80^{\circ} \mathrm{C}$ for further laboratory use. For isoenzyme extraction, approximately $0.5 \mathrm{~g}$ of tissue was homogenized in $10 \mathrm{~mL}$ saline solution (PBS, $\mathrm{pH}=6.8$ ), using a manual Homogenizer. The homogenates were centrifuged at $5000 \mathrm{rpm}$ for $10 \mathrm{mi}-$ nutes and the supernatants were kept at $-20^{\circ} \mathrm{C}$ until use. The enzymes; Alfa-esterase $(\alpha-E s t)$ in heart and Lactate dehydrogenase $(L d h)$ in liver supernatants were separated by discontinuous polyacrylamide gel electrophoresis [9] [10].

Electrophoresis was carried out conveniently in discontinuous polyacrylamide gels. An amount of $50 \mu 1$ of the clear supernatant of the liver and muscle homogenate of each sample was mixed with $20 \mu \mathrm{l}$ of protein dye (1\% bromophenol blue) and $20 \mu \mathrm{l}$ of $2 \%$ sucrose. Thirty $\mu \mathrm{l}$ of the mixture per gel slot were applied per each sample for isoenzymes electrophoresis. After electrophoresis, the gel was transferred into a staining solution (50 - $70 \mathrm{ml}$ ) according to [11], which was then replaced by a destaining mixture of methanol, acetic acid and water (5:1:5 $\mathrm{v} / \mathrm{v} / \mathrm{v})$. A potential gradient of high voltage electrode $[(20 \mathrm{v} / \mathrm{cm})$, anode $]$ across the gel was applied for $4 \mathrm{~h}$ at $8^{\circ} \mathrm{C}$ to separate the enzymes.

For $L d h$ and the electrophoresis after it, the gel was soaked in $100 \mathrm{~mL}$ of $0.2 \mathrm{M}$ Tris- $\mathrm{HCl}(\mathrm{pH}$ 8.0) containing $30 \mathrm{mg}$ NBT, $25 \mathrm{mg}$ EDTA, $50 \mathrm{mg}$ NAD, $10 \mathrm{mg}$ L-Lactic acid and $2 \mathrm{mg}$ PMS. There was $0.05 \mathrm{M}$ Tris-HCl pH 8.5 prepared by dissolving $0.605 \mathrm{~g}$ Tris in $50 \mathrm{~mL}$ distilled water. The $\mathrm{pH}$ was adjusted to $8.5 \mathrm{by} \mathrm{HCl}$. Then the solution was completed to $100 \mathrm{ml}$ by distilled water [12].

Regarding $\alpha$-Est, after the electrophoresis, the gel was soaked in $0.5 \mathrm{M}$ borate buffer (pH 4.1) for 90 minutes at $4^{\circ} \mathrm{C}$. This procedure lowers the $\mathrm{pH}$ of the gel from 8.8 to about 7 at which the reaction proceeds readily. The low temperature minimizes diffusion of the protein within the gel. The gel then was rinsed rapidly in two changes of double distilled water. The gel was stained for esterase activity by incubation at $37^{\circ} \mathrm{C}$ in a substrate solution of $100 \mathrm{mg} \alpha$-naphthyl acetate and $100 \mathrm{mg}$ fast blue RR salt in $200 \mathrm{ml}$ of $0.1 \mathrm{M}$ phosphate buffer $\mathrm{pH} 6.5$ [13].

After the appearance of the enzyme bands, the reaction was stopped by washing the gel two or three times 


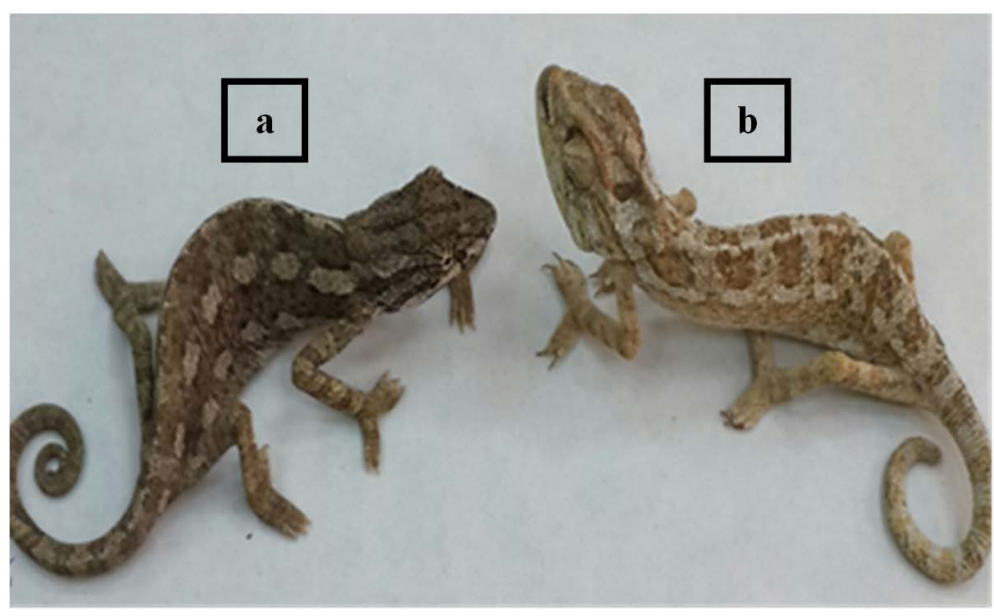

Figure 1. Photos of C. c. chamaeleon (a) and C. c. musae (b) inhabiting ElDabaa (MarsaMatrouh) and El-Arish (North Sinai) respectively.

with tap water. This was followed by adding the fixative solution, which consists of ethanol and $20 \%$ glacial acetic acid $(9: 11 \mathrm{v} / \mathrm{v})$. The gel was kept in the fixative solution for 24 hours and then photographed.

\subsection{Metabolic Study}

Immediately after collection, chamaeleons were weighed in grams (g) to the nearest $0.01-0.1 \mathrm{~g}$ and dissected. Pieces of liver and thigh muscles were removed and immediately weighed in grams (g) to the nearest $0.01 \mathrm{~g}$. They were stored frozen at $-20^{\circ} \mathrm{C}$ till use. Livers and thigh muscles were processed to estimate the total lipids and total proteins according to the method of [14] and [15] respectively, using a kit of Biodiagnostics Company.

\section{Statistics}

All gels were scanned using Gel Doc-2001 Bio-Rad system. For isoenzymes, the bands of enzyme activity were designated according to the system nomenclature proposed by [16].

An abbreviation which corresponds to the name of the enzyme was designated to each locus. When multiple loci were involved, the fastest anodal protein band was designated as Locus One, the next as Locus Two and so on. Student t-test in the PASW package v. 20 was used to calculate the significance difference of total lipids and total proteins within and between species.

\section{Results and Discussion}

Three $L d h$ isoforms were recorded for both subspecies of $C$. chanaeleon. The activity of $L d h$ - 1 isoform seemed to be higher in C. c. chanaeleon than in C. c. musaebecause greater thickness, density, and the rate of flow (RF) of the band in C. c. chanaeleonwas observed (Figure 2). Ldhsisozymes are systems that both very suitable systems for studying several metabolic, genetic, ecological features, and are very useful in systematic studies [6]. $L d h s$ are ahydrogen transfer enzymes that catalyze the oxidation of L-lactate to pyruvate with nicotinamideadenine dinucleotide (NAD)+ as hydrogen acceptor, the final step in the metabolic chain of anaerobic glycolysis. The reaction is reversible and the reaction equilibrium strongly favours the reverse reaction, namely the reduction of pyruvate $(\mathrm{P})$ to lactate $(\mathrm{L})$ :

$$
\text { L-lactate }+\mathrm{NAD}^{+} \underset{\mathrm{pH} 7.4-7.8}{\stackrel{\mathrm{LDH}, \mathrm{pH} 8.8-9.8}{\leftrightarrows}} \text { Pyruvate }+\mathrm{NADH}+\mathrm{H}^{+}
$$

Due to its ability to produce NADH, this enzyme is thought to be a key enzyme in lipid biosynthesis. The apparent increase in the activity of $L d h$ in liver tissues of $C$. c. chanaeleon, in the present study, could be supported by the significant increase in the total lipids and proteins in liver and muscle tissues of this subspecies. This subspecies is also shown to be fattier than C. c. musae. It may thus be reasonable to suppose that C. c. chanaeleon is more active, energetic, and adaptable in its habitat than C. c. musae. 
The $\alpha$-Est showed four fractions in both subspecies of chamaeleons except in the case of the last sample in $C$. c. musae, which showed three fractions with absence of the third fraction. The fractions of the two subspecies of chamaeleons were the same in terms of density and thickness. And their rates of flow were nearly the same (Figure 3). Esterases are used as bioindicators to measure the toxic potency of pesticide residues usually applied in the field [6] [7]. The null variations in the activity of $\alpha$-Ests in the studied tissue may indicate, to some extent, the safety of the diet applied to both subspecies of chameleons.

Table 1 shows the mean and standard error values of total lipids and proteins in liver and muscle tissues of

\begin{tabular}{|c|c|c|c|c|c|c|c|c|c|c|}
\hline \multirow{3}{*}{$\begin{array}{l}L d h-3 \\
L d h-2\end{array}$} & 1 & 2 & 3 & 4 & 5 & 6 & 7 & 8 & 9 & 10 \\
\hline & 5 & 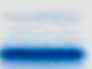 & 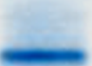 & 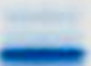 & 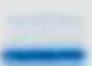 & 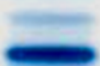 & 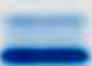 & 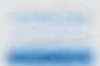 & 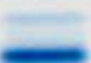 & 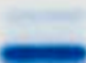 \\
\hline & 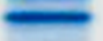 & $m$ & $\longrightarrow$ & -5 & - & 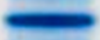 & 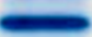 & $=$ & 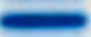 & 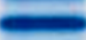 \\
\hline$L d h-1$ & 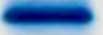 & & - & 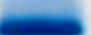 & 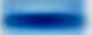 & & 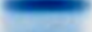 & & & \\
\hline Bands & RF & $\mathbf{R F}$ & RF & RF & RF & RF & RF & RF & RF & RF \\
\hline 3 & 0.1 & 0.11 & 0.12 & 0.11 & 0.12 & 0.11 & 0.12 & 0.13 & 0.12 & 0.1 \\
\hline 2 & 0.35 & 0.36 & 0.36 & 0.35 & 0.36 & 0.36 & 0.37 & 0.35 & 0.36 & 0.36 \\
\hline 1 & 0.85 & 0.75 & 0.78 & 0.93 & 0.86 & 0.56 & 0.75 & 0.68 & 0.7 & 0.67 \\
\hline
\end{tabular}

Figure 2. The electrophoretic profile of $L d h$ isoenzymes in liver tissues. Lanes are as follow: 1 - 5 (C. c. chanaeleon), 6 - 10 (C. c. musae).

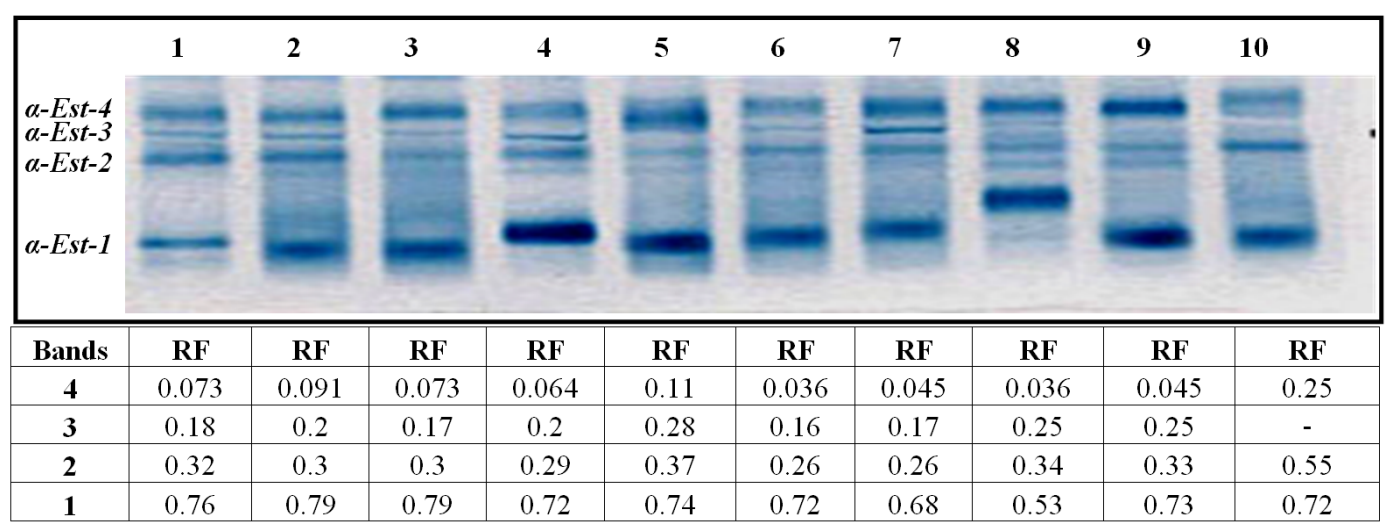

Figure 3. The electrophoretic profile of $\alpha$-Est isoenzymes in the studied heart tissues. Lanes are as follow: 1 5 (C. c. chanaeleon), 6 - 10 (C. c. musae).

Table 1. Comparison of total lipids and total proteins in liver and muscle tissues of C. c. chamaeleon and C. c. musae. Data are expressed as mean \pm standard error. Number of individuals between parentheses.

\begin{tabular}{cccc}
\hline Parameters & C. c. chamaeleon & C. c. musae & t-test \\
\hline Liver total lipids (mg/100 $\mathbf{~ m g )}$ & $19.2807 \pm 7.04712(5)$ & $8.4262 \pm 1.40782(5)$ & $1.981^{*}$ \\
Thigh muscle total lipids (mg/100 $\mathbf{~ m g )}$ & $4.5158 \pm 1.05328(5)$ & $4.1712 \pm 1.47154(5)$ & $5.080^{*}$ \\
$t$-test & $2.768^{*}$ & $5.277^{*}$ & \\
Liver total proteins (mg/100 $\mathbf{~ m g ) ~}$ & $153.7200 \pm 48.56457(5)$ & $79.3716 \pm 14.09141(5)$ & $1.353^{*}$ \\
Thigh muscle total proteins (mg/100 $\mathbf{~ m g )}$ & $5.4376 \pm 1.76793(5)$ & $5.1715 \pm 2.22419(5)$ & $4.525^{*}$ \\
$t$-test & $2.295^{*}$ & $4.610^{*}$ & \\
Body weight (g) & $25.0200 \pm 0.95677(5)$ & $24.0250 \pm 2.64650(5)$ & 0.388 \\
\hline
\end{tabular}

\footnotetext{
Highly significant at $\mathrm{P}<0.05$.
} 
both subspecies of chamaeleons. By comparing the total lipids and total proteins of liver and muscle tissues in the two $C$. chamaeleonsubspecies, one canfindasignificantly bigger increase $(\mathrm{P}<0.05)$ of the total lipids and total proteins in liver and muscle tissues of $C$. c. chamaeleon than in C. c. musae. Within each subspecies, total lipids and proteins were significantly higher in liver $(\mathrm{P}<0.05)$ tissues than in muscle.

In conclusion, C. c. chamaeleon acquired high physiological performance and activity than C. c. musae. Between the two, isoenzyme expression in the former species was higher than in the latter. The accumulation of total lipids and proteins were also significantly higher in the former subspecies than in the latter.

\section{Acknowledgements}

We are grateful to Prof. Dr. Hany Hassan, professor at Animal Reproduction Research Institute for his technical support in conducting the practical part of isoenzyme assay in this work.

\section{References}

[1] Tilbury, C.R. (2010) Chameleons of Africa-An Atlas Including the Chameleons of Europe, The Middle East and Asia. Chimaira Publications, Frankfurt am Main.

[2] Keren-Rotem, T., Bouskila, A. and Geffen, E. (2006) Ontogenetic Habitat Shift and Risk of Cannibalism in the Common Chameleon (Chamaeleo chamaeleon). Behavioral Ecology and Sociobiology, 59, 723-731. http://dx.doi.org/10.1007/s00265-005-0102-z

[3] Myers, P., Espinosa, R., Parr, C.S., Jones, T., Hammond, G.S. and Dewey, T.A. (2006) Family Chamaeleonidae. http://animaldiversity.ummz.umich.edu/site/accounts/classification/Chamaeleonidae.html\#Chamaeleonidae

[4] Dimaki, M., Valakos, E. and Legakis, A. (2000) Variation in body temperatures of the African chameleon Chamaeleoafricanus Laurenti, 1768 and the Common Chameleon Chamaeleo chamaeleon (Linnaeus, 1758). Belgium Journal of Zoology, 130, 87-91.

[5] Baha El Din, M. (2006) A Guide to Reptiles and Amphibians of Egypt. American University in Cairo Press, Cairo, 359 p.

[6] Al-Harbi, M.S. and Amer, S.A.M. (2012) Comparison of Energy-Related Isoenzymes between Production and Racing Arabian Camels. Advances in Bioscience and Biotechnology, 3, 1124-1128. http://dx.doi.org/10.4236/abb.2012.38138

[7] Shahjahan, R.M., Karim, A., Begum, R.A., Alam, M.S. and Begum, A. (2008) Tissue Specific Esterase Isozyme Banding Pattern in Nile Tilapia (Oreochromisniloticus). Universal Journal of Zoology (Rajshahi University), 27, 1-5.

[8] Hamrick, B.D. (1990) Gel Electrophoresis of Proteins. Oxford University Press, England.

[9] Maurer, R. (1968) Disk Electrophorese. W. de Gruyter and Co., Berlin, 222 p.

[10] Shaw, C.R. and Prasad, R. (1970) Starch Gel Electrophoresis of Enzymes: A Compilation of Recipes. Biochemistry and Genetics, 4, 297-329. http://dx.doi.org/10.1007/BF00485780

[11] Mulvey, M. and Vrijenhoek, R.C. (1981) Genetic Variation among Laboratory Strains of the Planorbid Snail; Biomphalariaglabrata. Biochemistry and Genetics, 19, 1169-1182. http://dx.doi.org/10.1007/BF00484572

[12] Jonathan, F.W. and Wendel, N.F. (1990) Visualization and Interpretation of Plant Isozymes. In: Soltis, D. E. and Soltis, P. S., Eds., Isozymes in Plant Biology, Champan and Hall, London, 5-45.

[13] Scandaliojs, G. (1964) Tissue-Specific Isozyme Variations in Maize. Journal of Heredity, 55, 281-285.

[14] Zöllner, N. and Kirsch, K. (1962) Colorimetric Method for Determination of Total Lipids. Journal of Experimental Medicine, 135, 545-550. http://dx.doi.org/10.1007/BF02045455

[15] Gornall, A.G., Bardawill, C.J. and David, M.M. (1949) Determination of Serum Proteins by Means of the Biuret Reaction. Journal of Biological Chemistry, 177, 751-766.

[16] Shaklee, J.B., Allendorf, F.W., Morizot, D.C. and Whitt, G.S. (1990) Gene Nomenclature for Protein Coding Loci in Fish. Transactions of the American Fisheries Society, 119, 2-15. http://dx.doi.org/10.1577/1548-8659(1990)119<0002:GNFPLI >2.3.CO;2 
Scientific Research Publishing (SCIRP) is one of the largest Open Access journal publishers. It is currently publishing more than 200 open access, online, peer-reviewed journals covering a wide range of academic disciplines. SCIRP serves the worldwide academic communities and contributes to the progress and application of science with its publication.

Other selected journals from SCIRP are listed as below. Submit your manuscript to us via either submit@scirp.org or Online Submission Portal.
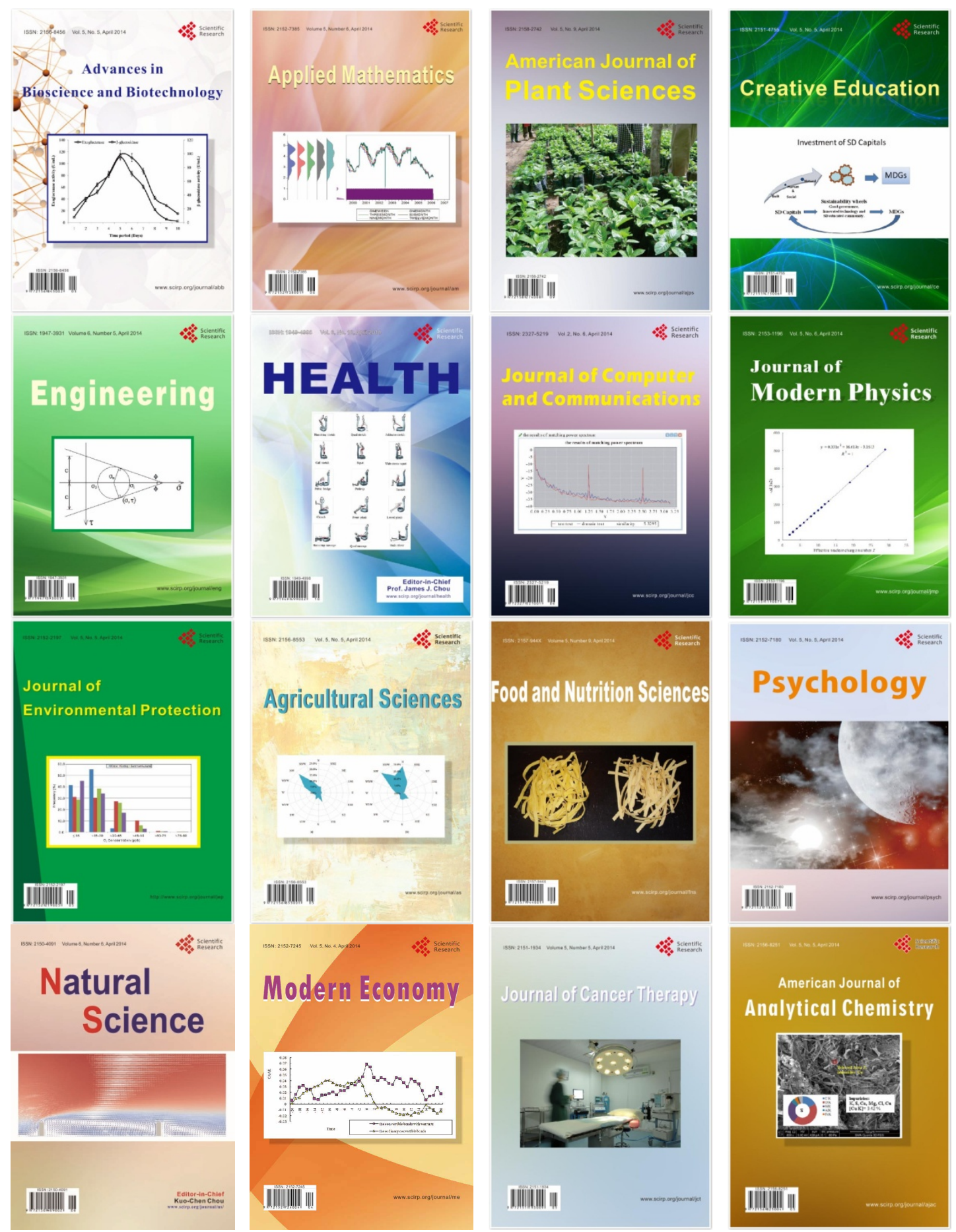